\title{
PERAN KELOMPOK TANI TERHADAP ANGGOTA KELOMPOK TANI KELELONDEI INDAH DI DESA AMPRENG KECAMATAN LANGOWAN BARAT
}

\author{
Romario Hevrain Palar \\ Charles Reijaaldo Ngangi \\ Benu Olfie Liesje Susana
}

\begin{abstract}
This study aims to determine the role of farmer groups on members of the Kelelondei Indah Farmers Group in Ampreng Village, Langowan Barat District, Minahasa Regency. This research was conducted for 3 months from October to December 2018. The data used in this study were primary and secondary data. Primary data collection through direct interviews to 20 respondents based on questionnaires that have been prepared previously. Secondary data was obtained from the Ampreng Village office and from google searching to get relevant theses. The results showed that the role of farmer groups on members of the Kelelondei Indah Farmers Group was generally good because of the 9 roles there were 7 roles categorized as good. They are increasing productivity to increase income, developing self-sufficiency in farming, teaching and learning containers for members, cooperating in facing threats among fellow farmers, achieving economies of scale together in terms of quality, a place to strengthen farmer cooperation, develop farming business carried out by members of farmer groups. While there are 2 roles categorized as not good, namely a place to strengthen cooperation between farmer groups and other parties, and develop farming business which is carried out together as a group business entity. "eprm*
\end{abstract}

Keywords: roles, farmer groups, Kelelondei Indah, Ampreng Village, Minahasa Regency

\begin{abstract}
ABSTRAK
Penelitian ini bertujuan untuk mengetahui Peran kelompok Tani terhadap anggota Kelompok Tani Kelelondei Indah di Desa Ampreng, Kecamatan Langowan Barat, Kabupaten Minahasa. Penelitian ini dilakukan selama 3 bulan dari bulan Oktober hingga Desember 2018. Data yang digunakan pada penelitian ini adalah data primer dan sekunder. Pengumpulan data primer melalui wawancara lansung kepada 20 responden berdasarkan kuesioner yang telah disusun sebelumnya. Data sekunder diperoleh dari kantor Desa Ampreng dan dari google searching untuk mendapatkan skripsi-skripsi yang relevan. Hasil penelitian menunjukkan peran kelompok tani terhadap anggota Kelompok Tani Kelelondei Indah secara umum tergolong baik karena dari 9 peran ada 7 peran yang dikategorikan baik, yaitu meningkatkan produktivitas untuk menambah pendapatan, menumbuh kembangkan kemandirian dalam berusaha tani, wadah belajar mengajar bagi anggotanya, bekerjasama dalam menghadapi ancaman di antara sesama petani, mencapai skala ekonomi secara bersama dari segi kualitas, tempat untuk memperkuat kerjasama petani, mengembangkan usaha tani yang dilakukan oleh anggota kelompok tani. Sedangkan ada 2 peran dikategorikan tidak baik, yaitu tempat untuk memperkuat kerjasama antara kelompok tani serta dengan pihak lain, dan mengembangkan usaha tani yang dilakukan secara bersama sebagai suatu kesatuan usaha kelompok. ${ }^{\text {eprmm* }}$
\end{abstract}

Kata Kunci : peran, kelompok tani, Kelelondei Indah, Desa Ampreng, Kabupaten Minahasa

\section{PENDAHULUAN}

\section{Latar Belakang}

Semua makhluk hidup diciptakan dengan peranannya masing-masing untuk dijalankan. Menurut Soekanto (2009) peran adalah proses dinamis kedudukan (status). Apabila seseorang melaksanakan hak dan kewajiban sesuai dengan kedudukannya, berarti dia menjalankan suatu peran. Manusia sebagai makhluk sosial pun dalam menjalani proses kehidupan tidak bisa lepas dari keberadaan orang-orang di sekitarnya, sehingga sejak awal manusia sudah hidup dalam suatu kelompok kecil yaitu keluarga yang menjadi tempat seseorang belajar mengenal normanorma kehidupan, belajar berinterkasi dengan orang lain serta belajar memahami peranannya dalam hidup bermasyarakat.

Secara khusus dalam dunia pertanian ada kelompok yang dubuat sebagai wadah masyarakat untuk bersosialisasi dengan sesamanya yaitu kelompok tani. Kelompok tani adalah kumpulan petani yang terikat secara non formal dan di bentuk atas dasar 
kesamaan, kepentingan, kesamaan kondisi lingkungan (sosial, ekonomi, sumberdaya), keakraban dan keserasian, serta mempunyai pimpinan untuk mencapai tujuan bersama (Dinas Pertanian Tanaman Pangan, 2002). Dalam upaya menuju pembangunan pertanian yang lebih maju, peran kelompok tani perlu didorong untuk memberikan kontribusi terhadap hal tesebut. Kelompok tani menjadi sebuah penggerak utama untuk mencapai kemajuan pertanian, kelompok tani juga memiliki peran penting dalam pembangunan pertanian.

Upaya membangun pertanian melalui kelompok tani memang bukan persoalan yang mudah karena ada banyak hal yang menjadi tantangan terutama pada era sekarang ini, salah satunya adalah kurangnya perhatian terhadap sektor pertanian dari berbagai pihak. Hal ini terjadi karena adanya pemahaman bahwa usaha pertanian kurang memberikan sumbangan pendapatan yang besar secara cepat terhadap perkembangan ekonomi. Ini tentunya berdampak pada keberadaan lembaga pertanian khususnya kelompok tani. Padahal kelompok tani merupakan aset yang berharga dalam rangka menuju pembangunan pertanian yang maju.

\section{Rumusan Masalah}

Berdasarkan latar belakang masalah yang dikemukakan maka rumusan masalahnya adalah : Bagaimana peran kelompok tani terhadap anggota kelompok tani Kelelondei Indah di Desa Ampreng Kecamatan Langowan Barat.

Tujuan Penelitian.

Tujuan penelitian yaitu: Untuk menganalisis peran kelompok tani terhadap anggota kelompok tani Kelelondei Indah di Desa Ampreng Kecamatan Langowan Barat.

\section{Manfaat Penelitian}

Manfat penelitian ini yaitu untuk melatih diri dalam membuat suatu karya ilmiah, untuk memberikan sumbangan pemikiran kepada lembaga dalam rangka studi agribisnis, dan untuk menghasilkan sebuah tulisan atau karya ilmiah yang dapat membantu kelompok-kelompok tani yang ada di pedesaan untuk mengetahui peran mereka.

\section{METODE PENELITIAN}

\section{Waktu dan Tempat Penelitian}

Penelitian ini dilaksanakan selama 3 bulan, yaitu sejak bulan Oktober sampai Desember 2018 mulai dari persiapan sampai penyusunan laporan. Tempat penelitian yaitu di Desa Ampreng Kecamatan Langowan Barat.

\section{Jenis dan Sumber Data}

Jenis dan sumber data yang dipakai dalam penelitian ini sebagai berikut :
1. Data Primer, data yang mengacu pada informasi yang diperoleh dari tangan pertama oleh peneliti yang berkaitan dengan variabel minat untuk tujuan spesifikasi studi (Uma Sekaran, 2011). Data primer dalam penelitian ini diperoleh melalui wawancara langsung kepada responden dengan menggunakan kuesioner yang disiapkan oleh peneliti.

2. Data Sekunder, data yang mengacu pada informasi yang dikumpulkan dari sumber yang telah ada (Uma Sekaran, 2011). Data sekunder dalam penelitian ini diperoleh melalui Kantor Desa tempat penelitian.

\section{Metode Pengumpulan Data}

Metode pengambilan data secara observasi dan kuesioner pada 1 kelompok tani yaitu Kelompok Tani "Kelelondei Indah" di Desa Ampreng yang terdiri dari 20 anggota/petani. Kelompok tani Kelelondei Indah dipilih sebabagi objek penelitian karena eksistensi atau keberadaan kelompok tani yang masih tetap bertahan sampai sekarang sejak dibentuknya kelompok tani ini yaitu pada tahun 2006 .

\section{Konsep Pengukuran Variabel}

Variabel yang diteliti terhadap anggota Kelompok Tani Kelelondei Indah sebagai berikut :

1. Gambaran Umum Kelompok Tani

1. Jenis Usaha

2. Jumlah Anggota

3. Struktur organisasi

2. Kuesioner Identitas Kelompok

1. Jenis Kelamin (Laki-laki / perempuan)

2. Umur (Tahun)

3. Tingkat Pendidikan Petani

3. Peran Kelompok Tani dianalisis sebagai berikut : 1. Kelas Belajar

a. Meningkatkan produktivitas untuk menambah pendapatan.

b. Menumbuhkembangkan kemandirian dalam berusaha tani.

c. Wadah belajar mengajar bagi anggotanya guna meningkatkan pengetahuan, sikap dan keterampilan.

2. Wadah Kerjasama

a. Bekerja sama dalam menghadapi ancaman, tantangan, hambatan dan gangguan.

b. Tempat untuk memperkuat kerjasama antar kelompoktani serta dengan pihak lain.

c. Tempat untuk memperkuat kerjasama di antara sesama petani.

3. Unit Produksi

a. Mencapai skala ekonomi secara bersama dengan menyeimbangkan hasil produk dari segi kuantitas, kualitas maupun kontinuitas.

b. Mengembangkan usaha tani yang dilakukan secara bersama sebagai suatu kesatuan usaha kelompok. 
c. Mengembangkan usaha tani yang dilakukan oleh masing-masing anggota kelompok tani.

\section{Analisis Data}

Analisis data yang digunakan dalam penelitian ini adalah dengan menggunakan skala likert untuk mengetahui peran kelompok tani Kelelondei Indah di Desa Ampreng Kecamatan Langowan Barat. Menurut Sugiyono (2012) skala likert adalah skala yang digunakan untuk mengukur sikap, pendapat, dan persepsi seseorang atau sekelompok orang tentang fenomena sosial. Dalam skala likert, variabel yang diukur dijabarkan menjadi indikator variabel. Kemudian indikator tersebut dijadikan sebagai titik tolak untuk menyusun item-item instrument yang berupa pernyataan-pernyataan. Dalam penelitian ini disusun pernyataan dan jawaban setiap instrument berupa kata-kata, yaitu :

$\mathrm{B}=$ Baik

$\mathrm{CB}=$ Cukup Baik

$\mathrm{TB}=$ Tidak Baik

Bila:

$\mathrm{B}$ diberi skor $=3$

$\mathrm{CB}$ diberi skor $=2$

TB diberi skor $=1$

Dengan cara perhitungan skor masing-masing pernyataan

Maka jumlah skor tiap kriteria capaian skor X jumlah responden

$\mathrm{S} 3=3 \times 9=27$

$\mathrm{S} 2=2 \times 9=18$

$\mathrm{S} 1=1 \times 9=9$

Jumlah skor ideal untuk setiap pernyataan skor (tertinggi) 27 dan jumlah skor terendah 9. Cara perhitungan skor keseluruhan untuk mengetahui peran kelompok tani terhadap anggota kelompok tani Kelelondei Indah

Jumlah skor seluruh kriterium = capaian jumlah skor $\mathrm{X}$ jumlah responden $\mathrm{X}$ instrument pernyataan.

$\mathrm{S} 3=3 \times 9 \times 15=405$

$\mathrm{S} 2=2 \times 9 \times 15=270$

$\mathrm{S} 1=1 \times 9 \times 15=135$

Jumlah skor ideal untuk keseluruhan pernyataan $=405$ (tinggi) dan jumlah skor rendah $=135$.

Peran Kelompok Tani $=\frac{\text { fumlah skor hasil pengumpulan data }}{\text { Jumlah skor ideal tertinggi }} \times 100 \%$

Dengan interpretasi nilai :

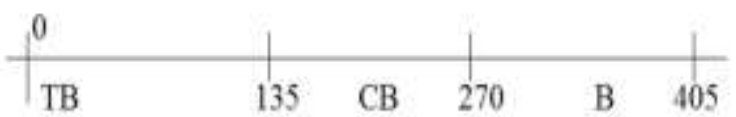

Dengan interpretasi persentase :

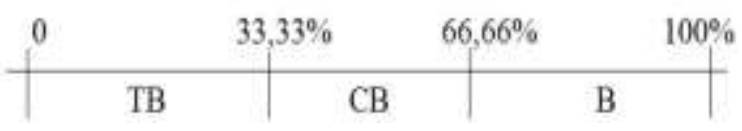

Keterangan kriteria interpretasi skor : Angka 0\% - 33,33\% Tidak Baik Angka 33,33\% - 66,66\% Cukup Baik Angka 66,66\% - 100\% Baik

\section{HASIL DAN PEMBAHASAN}

\section{Deskripsi Wilayah Penelitian}

Desa Tumani Selatan merupakan Desa yang terletak di Kecamatan Maesaan, Kabupaten Minahasa Selatan, Provinsi Sulawesi Utara. Terdiri dari 4 jaga/dusun. Dengan batas geografis wilayah.

\section{Letak dan Luas Wilayah}

Desa Ampreng adalah salah satu desa di Kecamatan Langowan Barat, dengan Luas Wilayah 74 ha yang terdiri dari 5 jaga. Adapun batas-batas desa yaitu :

1. Sebelah utara berbatasan dengan Desa Kopiwangker

2. Sebelah selatan berbatasan dengan Desa Tumaratas

3. Sebelah barat berbatasan dengan Perkebunan

4. Sebelah timur berbatasan dengan Desa Raringis

\section{Jumlah Penduduk}

Jumlah penduduk Desa Ampreng dapat di lihat pada Tabel 1.

Tabel 1. Jumlah Penduduk Desa Ampreng

\begin{tabular}{lcr}
\hline Jenis Kelamin & Jumlah Jiwa & Persentase (\%) \\
\hline Laki-laki & 672 & 53,58 \\
Perempuan & 582 & 46,61 \\
\hline \multicolumn{1}{c}{ Jumlah } & 1254 & 100 \\
\hline Sumber : Diolah dari data sekunder, 2018
\end{tabular}

\section{Mata Pencaharian}

Masyarakat di Desa Ampreng Kecamatan Langowan Barat memiliki mata pencaharian sebagai pegawai negeri sipil, petani, dan pedagang.

Total jumlah penduduk di Desa Ampreng Kecamatan Langowan Barat adalah 1254 jiwa. Sedangkan yang memiliki mata pencaharian sebagai petani lebih banyak dari pada pedagang dan PNS. Mata pencaharian penduduk Desa Ampreng dapat dilihat pada Tabel 2, jumlah persentase sebesar $64,26 \%$, pedagang sebesar $34,70 \%$ dan PNS sebesar $7,3 \%$ dengan jumlah penduduk yang memiliki mata pencaharian sebesar 873 jiwa. Sedangkan 381 jiwa belum memiliki pekerjaan karena terdiri dari anak balita, anak-anak SD, SMP, SMA dan Mahasiswa. 


\begin{tabular}{clcr}
\multicolumn{6}{c}{ Tabel 2. Mata Pencaharian Penduduk Desa Ampreng } \\
\hline No & Mata Pencaharian & Jumlah & Persentase (\%) \\
\hline 1 & PNS & 64 & 7,3 \\
2 & Petani & 561 & 64,26 \\
3 & Pedagang & 303 & 34,70 \\
\hline \multicolumn{7}{l}{ Jumlah } & 873 & 100 \\
\hline
\end{tabular}

Sumber : Diolah dari data sekunder, 2018

\section{Tingkat Pendidikan}

Pendidikan adalah salah satu unsur yang penting dalam usaha meningkatkan kualitas wawasan seseorang. Tingkat pendidikan setiap orang tentunya berbeda, begitu juga dengan tingkat pendidikan yang dimiliki oleh para responden juga berbeda.

\section{Gambaran Umum Kelompok Tani}

\section{Jenis Usaha}

Kelompok tani Kelelondei Indah yang dibentuk sejak tahun 2006 melaksanakan usaha pertanian dengan 3 jenis tanaman yang ditanam yaitu tomat, cabai dan jagung.

\section{Jumlah Anggota}

Kelompok tani Kelelondei Indah terdiri dari 4 orang pengurus dan 16 orang anggota. Jadi jumlah anggota kelompok secara keseluruhan adalah 20 orang.

\section{Struktur Organisasi}

Struktur Organisasi Kelompok Tani Kelelondei Indah sebagai berikut :

Ketua : Bpk. Alfian Sumigar

Wakil Ketua : Bpk. Jemi Palar

Sekretaris : Bpk. Godlief Lumenta

Bendahara : Ibu. Stella Lumenta

\section{Karakteristik Responden}

Jumlah responden dalam penelitian ini adalah 20 orang anggota kelompok tani. Gambaran umum mengenai responden disajikan menurut umur, jenis kelamin dan tingkat pendidikan.

\section{Umur Responden}

Kemampuan bekerja atau melakukan aktivitas secara fisik seseorang dapat dipengaruhi oleh faktor umur. Setiap responden sudah pasti memiliki umur/usia yang berbeda, berikut adalah variasi umur dari tiap responden.

Tabel 3 menunjukkan jumlah responden terbanyak adalah umur 51-60 tahun dengan jumlah responden 9 orang dan persentase sebesar $45 \%$.

\begin{tabular}{|c|c|c|c|}
\hline No & Umur (tahun) & Jumlah & Persentase (\%) \\
\hline 1 & $31-40$ & 3 & 15 \\
\hline 2 & $41-50$ & 6 & 30 \\
\hline 3 & $51-60$ & 9 & 45 \\
\hline 4 & $61-70$ & 2 & 10 \\
\hline & Jumlah & 20 & 100 \\
\hline
\end{tabular}

\section{Tingkat Pendidikan}

Pendidikan adalah salah satu unsur yang penting dalam usaha meningkatkan kualitas wawasan seseorang. Tingkat pendidikan setiap orang tentunya berbeda, begitu juga dengan tingkat pendidikan yang dimiliki oleh para responden juga berbeda.

Tabel 4 menunjukkan bahwa tingkat pendidikan responden terbanyak yaitu pada tingkat SMP yang berjumlah 10 responden dengan persentase $50 \%$ sedangkan tingkat pendidikan paling sedikit adalah pendidikan tingkat SD yaitu 4 orang responden dengan persentase $20 \%$.

\begin{tabular}{|c|c|c|c|}
\hline No & Pendidikan & Jumlah & Persentase (\%) \\
\hline 1 & SD & 4 & 20 \\
\hline 2 & SMP & 10 & 50 \\
\hline 3 & SMA & 6 & 30 \\
\hline & Jumlah & 20 & 100 \\
\hline
\end{tabular}

\section{Peran Kelompok Tani Terhadap Anggota Kelompok Tani Kelelondei Indah}

\section{Kelas Belajar}

Kelompok tani adalah wadah belajar mengajar bagi anggotanya untuk meningkatkan pengetahuan, sikap dan keterampilan serta menumbuhkembangkan kemandirian dalam berusaha tani sehingga produktivitasnya meningkat, pendapatannya bertambah serta kehidupannya lebih sejahtera.

\section{Meningkatkan produktivitas untuk menambah pendapatan}

Tabel 5 menunjukkan bahwa peran kelompok tani dalam meningkatkan produktivitas untuk menambah pendapatan anggota kelompoknya tergolong cukup baik.

\begin{tabular}{|c|c|c|c|c|}
\hline Alternatif Jawaban & $\begin{array}{l}\text { Alternatif } \\
\text { Skor }\end{array}$ & $\begin{array}{c}\text { Jumlah } \\
\text { Responden }\end{array}$ & $\begin{array}{c}\text { Persentase } \\
\text { Responden (\%) }\end{array}$ & Total Skor \\
\hline Baik & 3 & 11 & 55 & 33 \\
\hline Cukup Baik & 2 & 8 & 40 & 16 \\
\hline Tidak Baik & 1 & 1 & 5 & 1 \\
\hline Jumlah & 6 & 20 & 100 & 50 \\
\hline
\end{tabular}

\section{Menumbuhkembangkan kemandirian dalam berusaha tani.}

Tabel 6 menunjukkan bahwa peran kelompok tani terhadap anggota kelompoknya dalam hal menumbuhkembangkan kemandirian dalam berusaha tani tergolong cukup baik.

\begin{tabular}{|c|c|c|c|c|}
\hline $\begin{array}{l}\text { Alternatif } \\
\text { Jawaban }\end{array}$ & $\begin{array}{l}\text { Alternatif } \\
\text { Skor }\end{array}$ & $\begin{array}{c}\text { Jumlah } \\
\text { Responden }\end{array}$ & $\begin{array}{c}\text { Persentase } \\
\text { Responden }(\%)\end{array}$ & $\begin{array}{l}\text { Total } \\
\text { Skor }\end{array}$ \\
\hline Baik & 3 & 15 & 75 & 45 \\
\hline Cukup Baik & 2 & 5 & 25 & 10 \\
\hline Tidak Baik & 1 & - & - & - \\
\hline Jumlah & 6 & 20 & 100 & 55 \\
\hline
\end{tabular}




\section{Wadah belajar mengajar bagi anggotanya guna meningkatkan pengetahuan, sikap dan keterampilan}

Tabel 7 menunjukkan peran kelompok tani sebagai wadah belajar mengajar bagi anggota kelompok tani guna meningkatkan pengetahuan, sikap dan keterampilan tergolong cukup baik.

Tabel 7. Wadah belajar mengajar bagi anggotanya guna meningkatkan pengetahuan, sikap dan keterampilan

\begin{tabular}{|c|c|c|c|c|}
\hline $\begin{array}{l}\text { Alternatif } \\
\text { Jawaban }\end{array}$ & $\begin{array}{l}\text { Alternatif } \\
\text { Skor }\end{array}$ & $\begin{array}{c}\text { Jumlah } \\
\text { Responden }\end{array}$ & $\begin{array}{c}\text { Persentase } \\
\text { Responden }(\%)\end{array}$ & Total Skor \\
\hline Baik & 3 & 3 & 15 & 9 \\
\hline Cukup Baik & 2 & 15 & 75 & 30 \\
\hline Tidak Baik & 1 & 2 & 5 & 2 \\
\hline Jumlah & 6 & 20 & 100 & 41 \\
\hline
\end{tabular}

\section{Rekapitulasi Pengukuran Peran Kelompok Tani sebagai Kelas Belajar}

Hasil perhitungan seluruh peran kelompok tani sebagai Kelas belajar, maka disajikan rekapitulasi pada Tabel 8.

Tabel 8 menunjukkan bahwa terdapat 3 indikator peran kelompok tani dalam meningkatkan produktivitas untuk menambah pendapatan, menumbuhkembangkan kemandirian dalam berusaha tani dan sebagai wadah beajar mengajar bagi anggotanya guna meningatkan pengetahuan, sikap dan keterampilan mendapatkan interpretasi cukup baik.

Tabel 8. Rekapitulasi Pengukuran Peran Kelompok Tani

\begin{tabular}{llcc}
\multicolumn{5}{c}{ sebagai Kelas Belajar } & & \\
\hline No & \multicolumn{1}{c}{ Peran } & Total Skor & Interpretasi \\
\hline 1 & $\begin{array}{l}\text { Meningkatkan produktivitas untuk } \\
\text { menambah pendapatan }\end{array}$ & 50 & Cukup Baik \\
2 & $\begin{array}{l}\text { Menumbuhkembangkan kemandirian } \\
\text { dalam berusaha tani menajar bagi }\end{array}$ & 55 & Cukup Baik \\
3 & $\begin{array}{l}\text { Wadah belajar mengajar } \\
\text { anggota-nya guna meningkatkan } \\
\text { pengetahuan, sikap dan keterampilan }\end{array}$ & & Cukup Baik \\
\hline Sumber : Diolah dari data primer, 2018 & &
\end{tabular}

Sumber : Diolah dari data primer, 2018

Bekerjasama dalam menghadapi ancaman, tantangan, hambatan dan gangguan

Peran kelompok tani sebagai wadah untuk bekerjasama dalam menghadapi ancaman, tantangan, hambatan dan gangguan dapat dilihat pada Tabel 9.

Tabel 9 menunjukkan bahwa peran kelompok tani terhadap anggota kelompoknya sebagai wadah bekerjasama dalam menghadapi ancaman, tantangan, hambatan dan gangguan tergolong cukup baik.

Tabel 9. Bekerjasama dalam menghadapi ancaman, tantangan,

\begin{tabular}{ccccc} 
Tambatan dan gangguan & & \\
\hline Alternatif & $\begin{array}{c}\text { Alternatif } \\
\text { Jawaban }\end{array}$ & $\begin{array}{c}\text { Jumlah } \\
\text { Skor }\end{array}$ & $\begin{array}{c}\text { Persentase } \\
\text { Responden }\end{array}$ & Total Skor \\
\hline Baik & 3 & 2 & 10 & 6 \\
Cukup Baik & 2 & 10 & 50 & 20 \\
Tidak Baik & 1 & 8 & 40 & 8 \\
\hline Jumlah & 6 & 20 & 100 & 34 \\
\hline
\end{tabular}

Sumber : Diolah dari data primer, 2018
Tempat untuk memperkuat kerjasama antar kelompok tani serta dengan pihak lain serta dengan pihak lain

Peran kelompok tani sebagai tempat untuk memperkuat kerjasama antar kelompok tani serta dengan pihak lain. Dapat dilihat pada Tabel 10.

Tabel 10 menunjukkan bahwa peran kelompok tani sebagai tempat anggota kelompoknya untuk memperkuat kerjasama antar kelompok tani serta dengan pihak lain tergolong tidak baik.

Tabel 10. Tempat untuk memperkuat kerjasama antar kelompok tani serta dengan

\begin{tabular}{lcccc}
\multicolumn{2}{c}{ pihak lain } & & & \\
\hline \multicolumn{1}{c}{ Alternatif } & Alternatif & Jumlah & Persentase & Total Skor \\
Jawaban & Skor & Responden & Responden (\%) & \\
\hline Baik & 3 & 1 & 5 & 3 \\
Cukup Baik & 2 & 5 & 25 & 10 \\
Tidak Baik & 1 & 14 & 70 & 14 \\
\hline Jumlah & 6 & 20 & 100 & 27 \\
\hline
\end{tabular}

Sumber : Diolah dari data primer, 2018

Tempat untuk memperkuat kerjasama di antara sesama petani

Peran kelompok tani sebagai tempat untuk memperkuat kerjasama di antara sesama petani, dapat dilihat pada Tabel 11.

Tabel 1 menunjukkan bahwa peran kelompok tani sebagai tempat untuk memperkuat kerjasama di antara sesama anggota kelompok tani tergolong cukup baik.

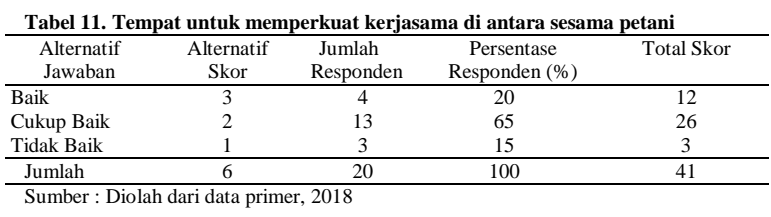

\section{Rekapitulasi Pengukuran Peran Kelompok Tani sebagai Wadah Kerjasama}

Hasil perhitungan seluruh peran kelompok tani sebagai wadah kerjasama, maka disajikan rekapitulasi dapat dilihat pada Tabel 11.

Tabel 12 menunjukkan bahwa terdapat tiga indikator peran kelompok tani sebagai wadah bekerjasama dalam menghadapi ancaman, tantangan, hambatan dan gangguan juga sebagai tempat untuk memperkuat kerjasama di antara sesama petani mendapatkan interpretasi cukup baik, sementara peran sebagai tempat untuk memperkuat kerjasama antar kelompok tani mendapatkan interpretasi tidak baik.

\begin{tabular}{|c|c|c|c|}
\hline Tab & $\begin{array}{l}\text { Rekapitulasi Pengukuran } \\
\text { Wadah Kerjasama }\end{array}$ & Kelom & Tani sebagai \\
\hline No & Peran & Total Skor & Interpretasi \\
\hline 1 & $\begin{array}{l}\text { Bekerjasama dalam menghadapi } \\
\text { ancaman, tantangan, hambatan } \\
\text { dan gangguan }\end{array}$ & 34 & Cukup Baik \\
\hline 2 & $\begin{array}{l}\text { Tempat untuk memperkuat } \\
\text { kerjasama antar kelompok tani } \\
\text { serta dengan pihak lain }\end{array}$ & 27 & Tidak Baik \\
\hline 3 & $\begin{array}{l}\text { Tempat untuk memperkuat kerjasama } \\
\text { di antara sesama petani }\end{array}$ & 41 & Cukup Baik \\
\hline
\end{tabular}


Mencapai skala ekonomi secara bersama dengan menyeimbangkan hasil produksi dari segi kuantitas, kualitas maupun kontinuitas

Peran kelompok tani sebagai unit produksi dalam mencapai skala ekonomi secara bersama dengan menyeimbangkan hasil produksi dari segi kuantitas, kualitas maupun kontinuitas, dapat dilihat pada Tabel 13 .

Tabel 13 menunjukkan bahwa peran kelompok tani sebagai unit produksi dalam mencapai skala ekonomi secara bersama dengan menyeimbangkan hasil produksi dari segi kuantitas, kualitas maupun kontinuitas tergolong cukup baik.

$\begin{aligned} & \text { Tabel 13. Mencapai skala ekonomi secara bersama dengan menyeimbangkan } \\
& \text { hasil produksi dari segi kuantitas, kualitas maupun kontinuitas }\end{aligned}$
\begin{tabular}{lccccc}
\hline $\begin{array}{c}\text { Alternatif } \\
\text { Jawaban }\end{array}$ & Alternatif & Jumlah & Persentase & Total Skor \\
\hline Baik & 3 & Responden & Responden $(\%)$ & \\
Cukup Baik & 2 & 4 & 20 & 12 \\
Tidak Baik & 1 & 11 & 55 & 22 & \\
\hline Jumlah & 6 & 5 & 25 & 5 & \\
\hline Sumber : Diolah dari data primer, 2018 & 20 & 100 & 39 \\
\hline
\end{tabular}

Mengembangkan usaha tani yang dilakukan secara bersama sebagai suatu kesatuan usaha kelompok

Peran kelompok tani sebagai unit produksi dalam mengembangkan usaha tani yang dilakukan secara bersama sebagai suatu kesatuan usaha kelompok, dapat dilihat pada Tabel 14.

Tabel 14 menunjukkan peran kelompok tani sebagai unit produksi dalam mengembangkan usaha tani yang dilakukan secara bersama sebagai suatu kesatuan usaha kelompok tergolong tidak baik.

\begin{tabular}{|c|c|c|c|c|}
\hline Tabel 14. & $\begin{array}{l}\text { Mengem } \\
\text { bersama }\end{array}$ & $\begin{array}{l}\text { angkan us: } \\
\text { bagai suat }\end{array}$ & $\begin{array}{l}\text { tani yang di } \\
\text { atuan usaha } 1\end{array}$ & $\begin{array}{l}\text { kan secara } \\
\text { ppok }\end{array}$ \\
\hline $\begin{array}{l}\text { Alternatif } \\
\text { Jawaban }\end{array}$ & $\begin{array}{l}\text { Alternatif } \\
\text { Skor }\end{array}$ & $\begin{array}{c}\text { Jumlah } \\
\text { Responden }\end{array}$ & $\begin{array}{c}\text { Persentase } \\
\text { Responden }(\%)\end{array}$ & Total Skor \\
\hline Baik & 3 & - & - & - \\
\hline Cukup Baik & 2 & 6 & 30 & 12 \\
\hline Tidak Baik & 1 & 14 & 70 & 14 \\
\hline Jumlah & 6 & 20 & 100 & 26 \\
\hline
\end{tabular}

\section{Mengembangkan usaha tani yang dilakukan} oleh masing-masing anggota kelompok tani

Peran kelompok tani sebagai unit produksi dalam mengembangkan usaha tani yang dilakukan oleh masing-masing anggota kelompok tani, dapat dilihat pada Tabel 15.

Tabel 15 menunjukkan bahwa peran kelompok tani sebagai unit produksi dalam mengembangkan usaha tani yang dilakukan oleh masing-masing anggota kelompok tani tergolong cukup baik.
Tabel 15. Mengembangkan usaha tani yang dilakukan oleh masingmasing anggota kelompok tani

\begin{tabular}{lcccc}
\multicolumn{5}{c}{ masing anggota kelompok tani } \\
\hline Alternatif & Alternatif & Jumlah & Persentase & Total Skor \\
Jawaban & Skor & Responden & Responden (\%) & \\
\hline Baik & 3 & 18 & 90 & 54 \\
Cukup Baik & 2 & 2 & 10 & 4 \\
Tidak Baik & 1 & - & - & - \\
\hline Jumlah & 6 & 20 & 100 & 58 \\
\hline Sumber : Diola dari
\end{tabular}

Sumber : Diolah dari data primer, 2018

\section{Rekapitulasi Pengukuran Peran Kelompok Tani sebagai Unit Produksi}

Tabel 16 menunjukkan bahwa terdapat tiga indikator peran kelompok tani sebagai unit produksi dalam mencapai skala ekonomi secara bersama dengan menyeimbangkan hasil produk dari segi kuantitas, kualitas dan kontinuitas mendapat interpretasi cukup baik, peran kelompok tani sebagai unit produksi dalam mengembangkan usaha tani yang dilakukan secara bersama sebagai suatu kesatuan usaha kelompok mendapat interpretasi tidak baik, sedangkan peran kelompok tani sebagai unit produksi dalam mengembangkan usaha tani yang dilakukan oleh masing-masing anggota kelompok mendapat interpretasi cukup baik.

Tabel 16. Rekapitulasi Pengukuran Peran Kelompok Tani

\begin{tabular}{llcc}
\multicolumn{4}{c}{ sebagai Unit Produksi } \\
\hline No & \multicolumn{1}{c}{ Peran } & Total Skor & Interpretasi \\
\hline 1 & $\begin{array}{l}\text { Mencapai skala ekonomi secara } \\
\text { bersama dengan menyeimbang-kan } \\
\text { hasil produk dari segi kuantitas, } \\
\text { kualitas maupun kontinuitas } \\
2\end{array}$ & 39 & Cukup Baik \\
& $\begin{array}{l}\text { Mengembangkan usaha tani yang } \\
\text { dilakukan secara bersama sebagai } \\
\text { suatu kesatuan usaha kelompok } \\
\text { Mengembangkan usaha tani yang } \\
\text { dilakukan oleh masing-masing } \\
\text { anggota kelompok }\end{array}$ & 26 & Tidak Baik \\
\hline Sumber : Diolah dari data primer, 2018 & & Cukup Baik \\
\end{tabular}

\section{Rekapitulasi Indeks Peran Kelompok Tani Terhadap Anggota Kelompok Tani Kelelondei Indah di Desa Ampreng Kecamatan Langowan Barat}

Penelitian ini untuk mengukur peran kelompok tani terhadap anggota kelompok tani Kelelondei Indah di Desa Ampreng, Kecamatan Langowan Barat dengan mengambil 9 peran sebagai tolak ukur dalam penelitian ini.

Tabel 17 menunjukkan peran kelompok tani sebagai tempat untuk memperkuat kerjasama antara kelompok tani serta dengan pihak lain dan peran sebagai unit produksi dalam mengembangkan usaha tani yang dilakukan secara bersama sebagai suatu kesatuan usaha kelompok mendapatkan hasil terendah dari 9 indikator lainnya, hal ini dikarenakan kelompok tani tidak melaksanakan kegiatan kerjasama dengan pihak 
lain. Kemudian peran sebagai unit produksi dalam mengembangkan usaha tani secara bersama tidak begitu baik dilaksanakan karena yang lebih menonjol adalah usaha tani yang dilakukan oleh masing-masing perorangan anggota kelompok. Hanya beberapa usaha saja yang dilakukan secara bersama.

\begin{tabular}{|c|c|c|c|}
\hline No & & & \\
\hline$\frac{1 N 0}{1}$ & & $\frac{5 \mathrm{SOI}^{2}}{50}$ & $\begin{array}{l}\text { Interpretasi } \\
\end{array}$ \\
\hline 1 & $\begin{array}{l}\text { Meningkatkan produktivitas untuk } \\
\text { menambah pendapatan }\end{array}$ & 50 & \\
\hline 2 & $\begin{array}{l}\text { Menumbuhkembangkan kemandirian } \\
\text { dalam berusaha tani }\end{array}$ & 55 & Cukup Baik \\
\hline 3 & $\begin{array}{l}\text { Wadah belajar mengajar bagi anggotanya } \\
\text { guna mengingkatkan pengetahuan, sikap } \\
\text { dan keterampilan }\end{array}$ & 41 & Cukup Baik \\
\hline 4 & $\begin{array}{l}\text { Bekerjasama dalam menghadapi } \\
\text { ancaman, tantangan, hambatan dan } \\
\text { gangguan }\end{array}$ & 34 & Cukup Baik \\
\hline 5 & $\begin{array}{l}\text { Tempat untuk memperkuat kerjasama } \\
\text { antara kelompok tani serta dengan } \\
\text { pihak lain }\end{array}$ & 27 & Tidak Baik \\
\hline 6 & $\begin{array}{l}\text { Tempat untuk memperkuat kerjasama } \\
\text { di antara sesama petani }\end{array}$ & 41 & Cukup Baik \\
\hline 7 & $\begin{array}{l}\text { Mencapai skala ekonomi secara bersama } \\
\text { dengan menyeimbangkan hasil produk } \\
\text { dari segi kuantitas, kualitas dan kontinuitas }\end{array}$ & 39 & Cukup Baik \\
\hline 8 & $\begin{array}{l}\text { Mengembangkan usaha tani yang } \\
\text { dilakukan secara bersama sebagai suatu } \\
\text { kesatuan usaha kelompok }\end{array}$ & 26 & Tidak Baik \\
\hline 9 & $\begin{array}{l}\text { Mengambangkan usaha tani yang dilaku } \\
\text { kan oleh masing-masing anggota } \\
\text { kelompok tani }\end{array}$ & 58 & Cukup Baik \\
\hline & Total Skor & 371 & \\
\hline
\end{tabular}

Selanjutnya peran kelompok tani sebagai kelas belajar dalam meningkatkan produktivitas untuk menambah pendapatan tergolong cukup baik karena dalam kelompok tani mereka belajar cara-cara yang dapat dilakukan untuk meningkatkan hasil produktivitas usaha pertanian yang ada sehingga pendapatan anggota kelompok pun bertambah. Peran kelompok tani sebagai kelas belajar untuk menumbuhkembangkan kemandirian dalam berusaha tani tergolong cukup baik karena para anggota kelompok belajar mengembangkan usaha pertanian mereka secara mandiri yaitu hal-hal dilakukan dengan usaha sendiri dari petani tersebut. Peran kelompok tani sebagai kelas belajar bagi anggotanya guna meningkatkan pengetahuan, sikap dan keterampilan tergolong cukup baik karena dari usaha pertanian yang dilakukan dalam kelompok membuat para anggotanya untuk menambah pengetahuan sikap dan keterampilan dalam bertani.

Peran kelompok tani sebagai wadah bekerjasama dalam menghadapi ancaman, tantangan, hambatan dan gangguan tergolong cukup baik karena dalam melakukan usaha pertanian di kelompok para anggotanya belajar mengenai apa saja hal-hal yang harus dilakukan ketika menghadapi ancaman, tantangan, hambatan dan gangguan baik dalam usaha pertanian maupun dalam berorganisasi. Peran kelompok tani sebagai tempat untuk memperkuat kerjasama di antara sesama petani tergolong cukup baik karena dari usaha pertanian yang dilakukan dan dalam organisasi yang dijalani secara bersama mereka belajar untuk bekerjasama atau bergotong royong dalam melaksanakan suatu pekerjaan.

Kemudian peran kelompok tani sebagai unit produksi untuk mencapai skala ekonomi secara bersama dengan menyeimbangkan hasil produksi dari segi kuantitas, kualitas maupun kontinuitas tergolong cukup baik karena dari usaha pertanian yang dilakukan kelompok membuat para anggota kelompok menjadikan kelompok tani yang mereka bentuk sebagai tempat untuk memproduksi tanaman tomat, cabai dan jagung dengan memperhatikan hasil kualitas tanaman, banyaknya hasil yang didapat dan keberlanjutan usaha pertanian yang akan dilakukan, dengan demikian skala ekonomi pun dicapai secara bersama-sama. Peran kelompok tani sebagai unit produksi dalam mengembangkan usaha tani yang dilakukan oleh masing-masing anggota kelompok tani tergolong cukup baik karena dari usaha pertanian yang dilakukan dalam kelompok dan pemanfaatan kelompok sebagai tempat untuk memproduksi tanaman cabai, tomat dan jangung mulai dari penanaman sampai pada panen yang dilakukan maka para anggota pun mempelajari cara-cara yang dilakukan sehingga mereka pun bisa melakukan hal tersebut secara mandiri yaitu dapat diterapkan secara sendirisendiri oleh setiap anggota kelompok tani.

Hasil untuk mengetahui peran kelompok tani terhadap anggota kelompok tani Kelelondei Indah di Desa Ampreng Kecamatan Langowan Barat, maka perlu dihitung jumlah keseluruhan skor pada setiap kriterium. Jumlah skor hasil penelitian ini mencapai 371. Dan jumlah skor ideal (skor tertinggi) adalah 405 dan jumlah skor terendah yaitu 135. Berdasarkan data yang diambil dari 9 peran yang diajukan pada 20 responden, maka peran kelompok tani terhadap anggota kelompok tani Kelelondei Indah terletak pada :

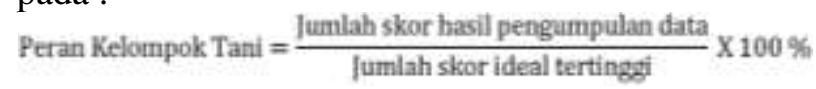

Peran Kelompok Tani $=\frac{371}{405} \times 100 \%=91,60 \%$ 
Dengan interpretasi persentase :

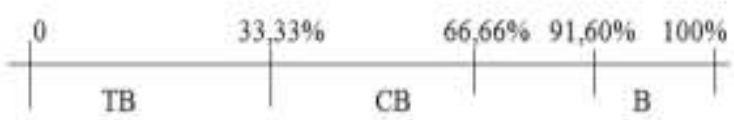

Dengan interpretasi nilai :

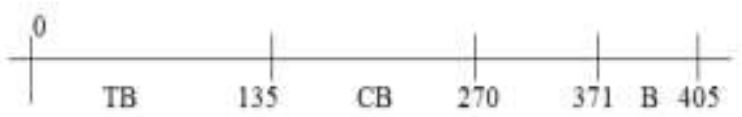

Keterangan kriteria interpretasi skor :

Angka 0\% - 33,33\% Tidak Baik

Angka 33,33\% - 66,66\%Cukup Baik

Angka 66,66\% - 100\%Baik

Hasil perhitungan di atas menunjukkan peran kelompok tani terhadap anggota kelompok tani Kelelondei Indah di Desa Ampreng Kecamatan Langowan Barat adalah 91,60\%. Artinya peran kelompok tani terhadap anggota kelompok tani tergolong baik karena dilihat dari 9 peran dimana 7 peran dikategorikan cukup baik dan 2 peran dikategorikan tidak baik. Meskipun peran kelompok tani terhadap anggota kelompok tani sudah baik tetapi hal ini harus tetap dipertahankan oleh kelompok tani yang ada, dan peran yang tergolong tidak baik sebaiknya dikembangkan lagi.

\section{KESIMPULAN DAN SARAN}

\section{Kesimpulan}

Hasil penelitian ini menunjukkan peran kelompok tani terhadap anggota kelompok tani Kelelondei Indah di Desa Ampreng Kecamatan Langowan Barat tergolong baik berdasarkan 9 peran yang telah diteliti kepada 20 responden.

\section{Saran}

Peran kelompok tani terhadap anggota kelompok tani Kelelondei Indah di Desa Ampreng Kecamatan Langowan Barat berada pada kategori baik. Hal ini menunjukkan bahwa kelompok tani sudah berperan dengan baik terhadap anggota kelompoknya. Meskipun demikian ditemui masih ada 2 poin peran yang masih tergolong tidak baik, jadi kelompok tani Kelelondi Indah sebaiknya lebih berusaha untuk meningkatkan kedua peran ini agar dapat berjalan dengan baik dan memberikan manfaat bagi anggota kelompok yang ada. Hasil yang telah dicapai melalui peran-peran yang sudah tergolong baik mulai dari peran kelompok sebagai kelas belajar, sebagai wadah kerjasama dan sebagai unit produksi agar tetap dipertahankan dan jangan sampai menurun.

\section{DAFTAR PUSTAKA}

Dinas Pertanian Tanaman Pangan Kalimantan Timur. 2002. Petunjuk Pelaksanaan Pembinaan Kelompok Tani. Kalimantan Timur (Diakses 7 September 2018).

Sekaran, Uma. 2011. Metode Penelitian untuk Bisnis. Salemba Empat. Jakarta.

Soekanto, Soerjono. 2009. Peranan Sosiologi Suatu Pengantar Edisi Baru.Rajawali Pers. Jakarta.

Sugiyono. 2012. Metode Penelitian Kualitatif dan R \& D. Alfabeta : Bandung. 